\title{
Feeding ecology of five commercial shark species of the Celtic Sea through stable isotope and trace metal analysis
}

\author{
N. Domi *, J.M. Bouquegneau, K. Das \\ Marine Research Center (MARE), Laboratory for Oceanology, University of Liege, \\ B6c Sart-Tilman, B-4000 Liege, Belgium
}

Received 24 June 2004; received in revised form 11 March 2005; accepted 23 March 2005

\begin{abstract}
In order to trace their feeding habits, stable carbon and nitrogen isotope ratios $\left(\delta^{15} \mathrm{~N}\right.$ and $\left.\delta^{13} \mathrm{C}\right)$, as well as trace metal concentrations $(\mathrm{Zn}, \mathrm{Cd}, \mathrm{Fe}, \mathrm{Cu}, \mathrm{Se}$ and $\mathrm{Hg}$ ) were analysed in the tissues of five commercial shark species from the Celtic Sea: the tope shark Galeorhinus galeus, the black-mouthed catshark Galeus melastomus, the starry smooth hound Mustelus asterias, the spiny dogfish Squalus acanthias and the lesser-spotted dogfish Scyliorhinus canicula. Our results were compared to previously described stomach contents and isotopic composition of potential preys. Isotopic ratio $\delta^{15} \mathrm{~N}$ suggested that tope sharks fed at a higher trophic level $(16.7 \%$ in the muscle) than the other species, reflecting its piscivorous diet. The lower values of spiny dogfish $(11.6 \%$ in the muscle) might be explained, amongst other things, by either its migratory behaviour or its preference for preys from lower trophic levels. Cd and $\mathrm{Hg}$ were correlated with isotopic ratios $\delta^{13} \mathrm{C}$ and $\delta^{15} \mathrm{~N}$, and were shown to be diet-related whereas $\mathrm{Zn}, \mathrm{Fe}$ and $\mathrm{Cu}$ seemed much more linked to species-specific metabolism. Although this multidisciplinary approach is revealed as a useful tool for the study of shark ecology, the lack of known trophic fractionation suggests that isotopic data be compared to traditional diet analyses.

(c) 2005 Elsevier Ltd. All rights reserved.
\end{abstract}

Keywords: Elasmobranchs; Stable isotopes; Trace metals; Trophic level; Celtic Sea; Galeorhinus galeus; Galeus melastomus; Mustelus asterias; Squalus acanthias; Scyliorhinus canicula

\footnotetext{
* Corresponding author. Tel.: +32 4366 3327; fax: +32 43663325 .

E-mail address: nadege.domi@student.ulg.ac.be (N. Domi).
} 


\section{Introduction}

The number of studies on trace metal accumulation in marine organisms has increased dramatically in recent years, mainly in fish and other species intended for direct or indirect human consumption. Top predators, particularly long-lived species such as marine mammals (Das et al., 2003), seabirds (Debacker, Schiettecatte, Jauniaux, \& Bouquegneau, 2001), billfishes (Kai, Hueda, Takeda, \& Kat, 1987), tunas (Das et al., 2000; Miller et al., 1972; Storelli, Giacominelli-Stuffler, \& Marcotrigiano, 2001) and mackerels (Meaburn, 1978) have been reported to accumulate high levels of trace metals such as mercury, and sometimes cadmium and other metals.

Sharks are top predators and are believed to play a significant role in aquatic food webs (Bowen, 1997). The mean trophic levels of sharks (Cortès, 1999) are similar to those described for marine mammals (Pauly, Trites, Capuli, \& Christensen, 1998) and are somewhat higher than those of seabirds (Hobson, 1993; Hobson, Piatt, \& Pitocchelli, 1994), whether estimated using dietary analyses or stable isotopes. As with marine mammals and seabirds, sharks are susceptible of accumulating significant levels of trace metals in their tissues. The recent increase in captures of elasmobranch species for human consumption in European waters (Biessi, 1994) justifies the need for pollutant monitoring in these species (Adams \& McMichael, 1999; Forrester \& Ketchen, 1972; Leah, Evans, \& Johnson, 1991; Storelli et al., 2001).

Stomach contents have long been used to assess diet and assign trophic levels in aquatic food webs (Cortès, 1997, 1999; Ellis, Pawson, \& Shackley, 1996). This data can be complemented by the analysis of the isotopic ratios of carbon $\left(\delta^{13} \mathrm{C}\right)$ and nitrogen $\left(\delta^{15} \mathrm{~N}\right)$ in the tissues. Stable isotopes of carbon $\left({ }^{13} \mathrm{C}\right)$ and nitrogen $\left({ }^{15} \mathrm{~N}\right)$ are useful to delineate and understand the trophic relationships and origins of prey in marine as well as in terrestrial food webs and so have allowed a new approach of feeding ecology (Fry \& Sherr, 1988, Chap. 12; Jarman, Hobson, Sydeman, Bacon, \& McLaren, 1992; Jarman et al., 1996; Michener \& Schell, 1994; Owens, 1988). This technique assumes that during the ingestion of food and excretion of wastes, there is an enrichment of the heavier isotope (i.e., ${ }^{13} \mathrm{C}$ or ${ }^{15} \mathrm{~N}$ ), a process known as fractionation (Olive, Pinnegar, Polunin, Richards, \& Welch, 2003). A predator will therefore have a higher proportion of the heavy isotope than the prey on which it feeds. The isotopic composition of an animal's tissue therefore reflects that of its prey with a slight trophic enrichment in ${ }^{13} \mathrm{C}$ and ${ }^{15} \mathrm{~N}$ of about $1 \%$ and $3.4 \%$, respectively (De Niro \& Epstein, 1978, 1981; Peterson \& Fry, 1987). $\delta^{15} \mathrm{~N}$ ratios are often used as a predictor of relative trophic level (Pinnegar, Jennings, O'Brien, \& Polunin, 2002; Post, 2002; Vander Zanden, Cabana, \& Rasmussen, 1997) whereas $\delta^{13} \mathrm{C}$ values can be useful in evaluating sources of primary production in marine systems : $\delta^{13} \mathrm{C}$ values are typically higher (less negative) in inshore/ benthic food webs and more negative in plankton-based systems (Dauby, Khomsi, \& Bouquegneau, 1998; Hobson, 1999; Hobson, Ambrose, \& Renaud, 1995). Stable isotope studies provide some advantages over stomach content analysis. They are based on assimilated and not just ingested food and they allow a comparison of the animal's short and long term feeding habits as the liver has a faster turn-over rate than the muscle, so that these tissues reflect an integrated diet over the past 
few days or weeks, respectively (Bosley, Witting, Chambers, \& Wainright, 2002; Hesslein, Hallard, \& Ramlal, 1993).

Studies of stomach contents have been carried out for various species of sharks (Cortès, 1999; Ellis et al., 1996) but few references on their isotopic composition are yet available in the literature (Estrada, Rice, Lutcavage, \& Skomal, 2003; Fisk, Tittlemier, Pranschke, \& Norstrom, 2002; Pinnegar et al., 2002). In this study, we determined the $\delta^{13} \mathrm{C}$ and $\delta^{15} \mathrm{~N}$ values of five shark species from the Celtic Sea, the tope shark Galeorhinus galeus, the black-mouthed catshark Galeus melastomus, the starry smooth hound Mustelus asterias, the spiny dogfish Squalus acanthias and the lesser-spotted dogfish Scyliorhinus canicula to trace their feeding habits, using also their stomach contents and the isotopic composition of their potential preys previously recorded in other studies (Ellis et al., 1996; Pinnegar et al., 2002). Zinc (Zn), lead $(\mathrm{Pb})$, nickel $(\mathrm{Ni})$, cadmium $(\mathrm{Cd})$, iron $(\mathrm{Fe})$, chromium $(\mathrm{Cr})$, copper $(\mathrm{Cu})$, selenium $(\mathrm{Se})$ and mercury $(\mathrm{Hg})$ concentrations were also examined for evidence of species differences, diet transfer, specific biomagnification processes. Moreover, limitations in the interpretation of stable isotope data were discussed.

\section{Materials and methods}

\subsection{Collection and storage}

The tissues (liver, kidney and muscle) of five commercial shark species, captured by trawl in May 2000 in the Celtic Sea (Northeast Atlantic) - tope shark Galeorhinus galeus $(n=6)$, black-mouthed catshark Galeus melastomus $(n=7)$, starry smooth hound Mustelus asterias $(n=7)$, spiny dogfish Squalus acanthias $(n=6)$ and lesserspotted dogfish Scyliorhinus canicula $(n=8)$ - were stored at $-20{ }^{\circ} \mathrm{C}$ until analysis. The sampling area is located between $48^{\circ} \mathrm{N}$ and $50^{\circ} \mathrm{N}$ and $5^{\circ} \mathrm{W}$ and $9^{\circ} \mathrm{W}$, ICES division VIIh (Fig. 1).

\subsection{Trace metal analysis}

After being weighed and dried for $48 \mathrm{~h}$ at $110^{\circ} \mathrm{C}$, liver and muscle samples were digested with a solution of nitric acid (Merck 456) and slowly heated to $100^{\circ} \mathrm{C}$ until complete digestion. Atomic absorption spectrophotometry (ARL 3510) was used to determine trace metal concentrations. Concentrations are expressed as $\mu \mathrm{g} \mathrm{g}^{-1} \mathrm{dry}$ weight (dw).

A set of certified standard materials were analysed in parallel (CRM 278 Community Bureau of Reference, Commission of the European Communities) to ensure the method's sensitivity. Recoveries ranged from $92 \%$ to $102 \%$ for $\mathrm{Zn}, \mathrm{Fe}$ and $\mathrm{Cu}$, and $88 \%$ for $\mathrm{Cd}$. Detection limits were $0.33 \mu \mathrm{g} \mathrm{g}^{-1} \mathrm{dw}$ for $\mathrm{Zn}, 0.16$ for $\mathrm{Fe}, 0.01$ for $\mathrm{Cu}$ and 0.22 for $\mathrm{Cd}$.

$\mathrm{Hg}$ was analysed by flameless atomic absorption spectrophotometry (PerkinElmer MAS-50A) after sulphuric acid digestion, as described by Joiris, Holsbeek, Bouquegneau, and Bossicart (1991). 


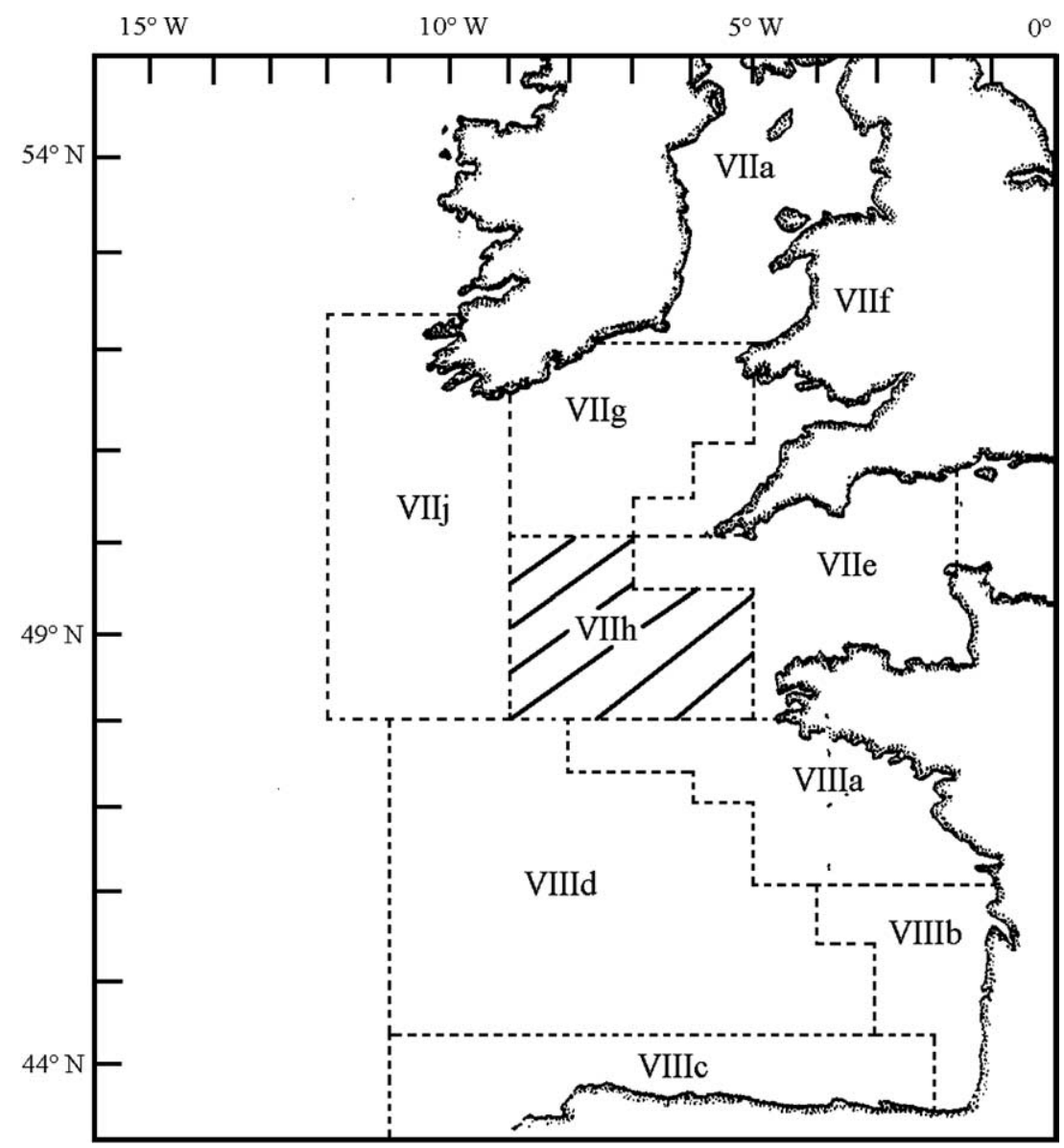

Fig. 1. Sampling area, ICES division VIIh (modified from Ellis et al., 1996).

Selenium was analysed by fluorimetry following complete digestion of the tissue by nitric, perchloric and hydrochloric acids, coupling to EDTA and 2,3-diaminonaphthalene and extraction by cyclohexane (modified from Mejuto Marti, Bollain Rodriguez, \& Martinez, 1987). The fluorimeter was set at excitation wavelength of $364 \mathrm{~nm}$ and emission wavelength of $523 \mathrm{~nm}$ with an emission slit of $2 \mathrm{~mm}$ and an integration time for read mode of $2 \mathrm{~s}$.

Quality control measurements for total $\mathrm{Hg}$ and $\mathrm{Se}$ included replicate analysis resulting in coefficients of variation $<10 \%$ and analysis of certified standard materials (DORM-1, NRC, Canada).

\subsection{Stable isotope measurements}

Organisms may vary in their concentrations of lipids. As lipids are depleted in ${ }^{13} \mathrm{C}$ relatively to the diet (Pinnegar \& Polunin, 1999), they were extracted from samples 
before analysis. Lipids are extracted using repeated 2:1 chloroform and methanol rinses. The residue is stored at $50{ }^{\circ} \mathrm{C}$ for at least $48 \mathrm{~h}$ and then reduced to a powder. Isotopic ratios of the samples were performed on a V.G. Optima (Micromass) IR-MS coupled to a N-C-S elemental analyser (Carlo Erba) for automated analysis. Stable isotope ratios are expressed in $\delta$ notation as parts per thousand $(\%)$ according to the following:

$$
\delta \mathrm{X}=\left[\left(R_{\text {sample }} / R_{\text {standard }}\right)-1\right] * 1000,
$$

in which $\mathrm{X}$ is ${ }^{13} \mathrm{C}$ or ${ }^{15} \mathrm{~N}, R_{\text {sample }}$ is the corresponding ratio ${ }^{13} \mathrm{C} /{ }^{12} \mathrm{C}$ or ${ }^{15} \mathrm{~N} /{ }^{14} \mathrm{~N}$ and $R_{\text {standard }}$ represents the ratio for the respective standard. The standards for ${ }^{13} \mathrm{C}$ and ${ }^{15} \mathrm{~N}$ are, respectively, V-PDB (Vienna - Pee Dee Belemnite) and atmospheric nitrogen $\mathrm{N}_{2}$. Reference materials were IAEA-N1 $\left(\delta^{15} \mathrm{~N}=+0.4 \pm 0.2 \%\right.$ ond IAEA CH-6 (sucrose) $\left(\delta^{13} \mathrm{C}=-10.4 \pm 0.2 \%\right.$ ). The precision calculated on 25 measurements of a standard sample was $\pm 0.3 \%$ for both isotopes.

\subsection{Data treatment}

The Kolmogorof-Smirnof test was used to test for data departure from normality. When not distributed normally the variables were log-transformed to normalize their distribution. Effects of species and tissues on $\delta^{13} \mathrm{C}$ and $\delta^{15} \mathrm{~N}$ values or trace metal concentrations were tested using univariate analysis of variance (one-way ANOVA) followed by post-hoc multiple comparison tests (Scheffe test). A Student's $t$-test was used to compare isotopic and metal concentration values between the different tissues analysed. When it was not possible to log-transform the data, the nonparametric Mann-Whitney $U$-test was used to compare differences among groups. The Pearson test (correlation factor $r_{\mathrm{p}}$ ) was used for correlation in the case of the variables following a normal distribution, otherwise the Spearman test (correlation factor $r_{\mathrm{s}}$ ) was used. Results were judged significant when $p<0.05$.

\section{Results}

\subsection{Stable isotope measurements}

$\delta^{15} \mathrm{~N}$ and $\delta^{13} \mathrm{C}$ values in muscle and liver and also the length of five commercial shark species are presented in Table 1 and Fig. 2. Except for spiny dogfish (Student $t$-test, $p=0.023$ ), mean $\delta^{13} \mathrm{C}$ values in the liver and muscle did not differ significantly. Muscle $\delta^{15} \mathrm{~N}$ values were significantly higher than those measured in liver in each species (Mann-Whitney $U$-test, $p<0.05$ ).

For both liver and muscle, $\delta^{15} \mathrm{~N}$ and $\delta^{13} \mathrm{C}$ measurements differed significantly between species (ANOVA, univariate results see Table 2). For $\delta^{15} \mathrm{~N}$ values, a clustering by species for both liver and muscle was observed: tope sharks displayed the highest $\delta^{15} \mathrm{~N}$ values while the spiny dogfish displayed the lowest (post-hoc Scheffe test, $p<0.0001$ ). Muscle and hepatic mean $\delta^{15} \mathrm{~N}$ data did not differ significantly between black-mouthed catsharks, starry smooth hounds and lesser-spotted dogfish 
Table 1

$\delta^{13} \mathrm{C}$ and $\delta^{15} \mathrm{~N}$ values (\%) in liver and muscle and lengths of five commercial shark species from the Celtic Sea

\begin{tabular}{|c|c|c|c|c|c|}
\hline \multirow[t]{2}{*}{ Species } & \multirow[t]{2}{*}{ Length } & \multicolumn{2}{|l|}{ Liver } & \multicolumn{2}{|l|}{ Muscle } \\
\hline & & $\delta^{13} \mathrm{C}$ & $\delta^{15} \mathrm{~N}$ & $\delta^{13} \mathrm{C}$ & $\delta^{15} \mathrm{~N}$ \\
\hline $\begin{array}{l}\text { Tope shark: } \\
\text { Galeorhinus galeus }\end{array}$ & $\begin{array}{l}\mathbf{7 7 . 8}(\mathbf{7 0 )} \pm \mathbf{1 8 . 3} \\
(63-102) \\
n=6\end{array}$ & $\begin{array}{l}-16.1(-15.8) \pm 0.6 \\
(-16.9 /-15.5) \\
n=6\end{array}$ & $\begin{array}{l}14.2(14) \pm 1.04 \\
(13-15.5) \\
n=6\end{array}$ & $\begin{array}{l}-\mathbf{1 5 . 5}(-\mathbf{1 5 . 5}) \pm \mathbf{0 . 5} \\
(-16.4 /-14.9) \\
n=6\end{array}$ & $\begin{array}{l}\mathbf{1 6 . 7}(\mathbf{1 6 . 4 )} \pm \mathbf{0 . 9} \\
(15.8-18.4) \\
n=6\end{array}$ \\
\hline $\begin{array}{l}\text { Black-mouthed catshark: } \\
\text { Galeus melastomus }\end{array}$ & $\begin{array}{l}\mathbf{6 2 . 6}(64) \pm \mathbf{4 . 5} \\
(54-66.5) \\
n=7\end{array}$ & $\begin{array}{l}-16.7(-16.8) \pm 0.3 \\
(-17 /-16) \\
n=7\end{array}$ & $\begin{array}{l}12.7(12.7) \pm 0.7 \\
(11.9-13.8) \\
n=7\end{array}$ & $\begin{array}{l}-17(-16.9) \pm 0.4 \\
(-17.6 /-16.6) \\
n=5\end{array}$ & $\begin{array}{l}14.4(14.4) \pm 0.2 \\
(14.2-14.8) \\
n=7\end{array}$ \\
\hline $\begin{array}{l}\text { Starry smooth hound: } \\
\text { Mustelus asterias }\end{array}$ & $\begin{array}{l}\mathbf{8 8 . 9}(\mathbf{8 8}) \pm \mathbf{6 . 2} \\
(78-95) \\
n=7\end{array}$ & $\begin{array}{l}-14.9(-14.6) \pm 1.3 \\
(-16.8 /-13.2) \\
n=7\end{array}$ & $\begin{array}{l}\mathbf{1 2 . 7}(\mathbf{1 2 . 7 )} \pm \mathbf{0 . 6} \\
(11.7-13.4) \\
n=7\end{array}$ & $\begin{array}{l}-\mathbf{1 5 . 8}(-\mathbf{1 5 . 8}) \pm \mathbf{1} \\
(-17 /-13.8) \\
n=7\end{array}$ & $\begin{array}{l}14.5(13.9) \pm 1.2 \\
(13.5-16.6) \\
n=7\end{array}$ \\
\hline $\begin{array}{l}\text { Spiny dogfish: } \\
\text { Squalus acanthias }\end{array}$ & $\begin{array}{l}\mathbf{6 3 . 2}(\mathbf{6 3 . 8 )} \pm \mathbf{2 . 3} \\
(60-66) \\
n=6\end{array}$ & $\begin{array}{l}-\mathbf{1 7 . 5}(-\mathbf{1 7 . 5}) \pm \mathbf{0 . 3} \\
(-18 /-17) \\
n=6\end{array}$ & $\begin{array}{l}\mathbf{1 0 . 6}(\mathbf{1 0 . 5}) \pm \mathbf{0 . 6} \\
(10-11.4) \\
n=6\end{array}$ & $\begin{array}{l}-17(-17.1) \pm 0.4 \\
(-17.3 /-16.4) \\
n=6\end{array}$ & $\begin{array}{l}\mathbf{1 1 . 6}(\mathbf{1 1 . 4 )} \pm \mathbf{0 . 6} \\
(11.1-12.8) \\
n=6\end{array}$ \\
\hline $\begin{array}{l}\text { Lesser-spotted dogfish: } \\
\text { Scyliorhinus canicula }\end{array}$ & $\begin{array}{l}\mathbf{6 1 . 1}(\mathbf{6 1 )} \pm \mathbf{3 . 0} \\
(55-64) \\
n=8\end{array}$ & $\begin{array}{l}-17(-17) \pm 1.4 \\
(-19.3 /-15) \\
n=8\end{array}$ & $\begin{array}{l}\mathbf{1 2 . 8}(\mathbf{1 2 . 6 )} \pm \mathbf{0 . 6} \\
(11.9-13.8) \\
n=8\end{array}$ & $\begin{array}{l}-\mathbf{1 6 . 2}(-\mathbf{1 6 . 1 )} \pm \mathbf{0 . 4} \\
(-16.7 /-15.8) \\
n=8\end{array}$ & $\begin{array}{l}14.4(14.6) \pm 0.6 \\
(13.3-15) \\
n=8\end{array}$ \\
\hline
\end{tabular}

Data are given as: average (median) \pm standard deviation, (minimum-maximum) and number of samples, $n$.

Length is expressed in centimeters. 

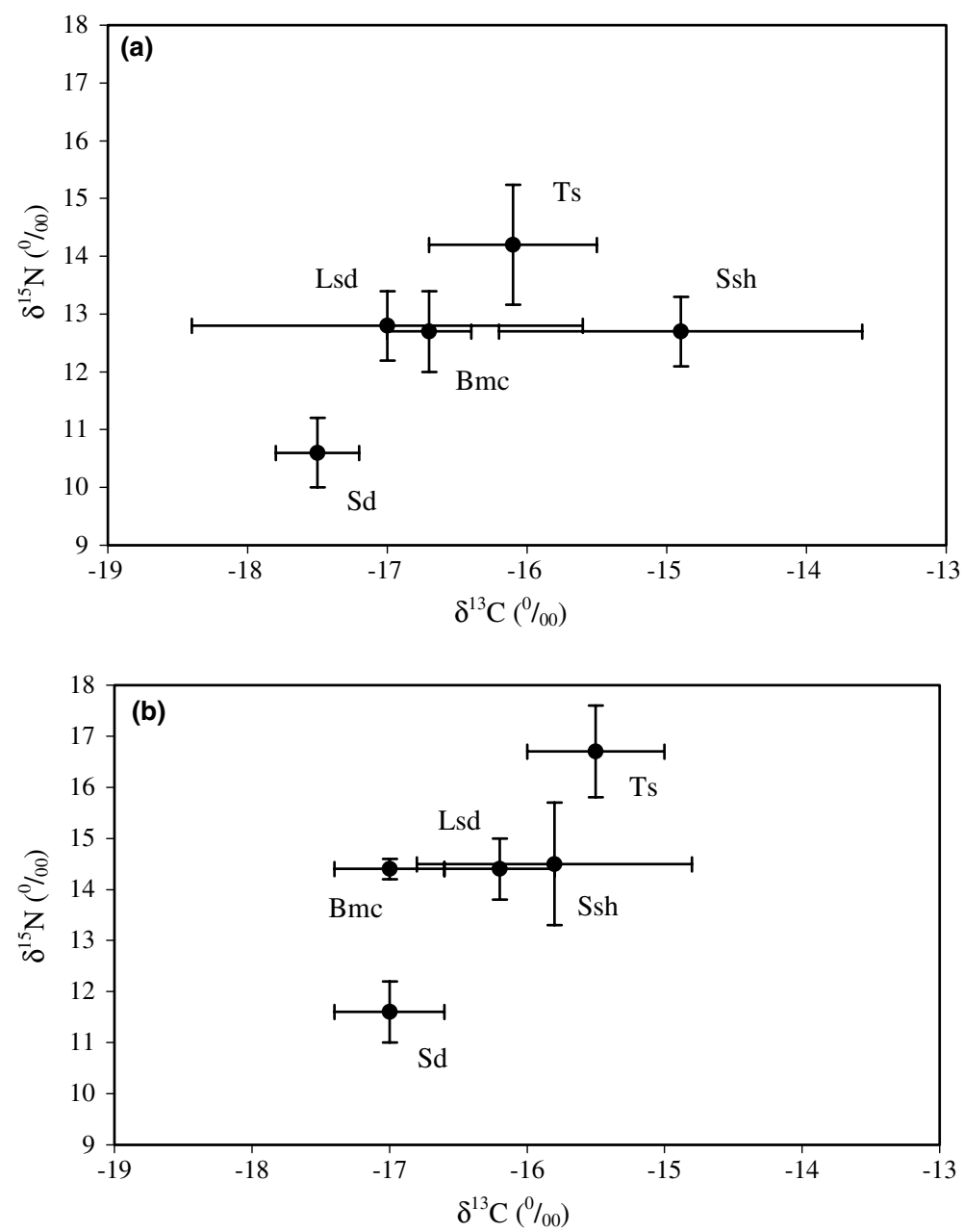

Fig. 2. Average $\delta^{13} \mathrm{C}$ and $\delta^{15} \mathrm{~N}$ values with standard deviation in the liver (a) and the muscle (b) of five shark species from the Celtic Sea. Ts: Tope shark, $n=6$; Bmc: Black-mouthed catshark, $n=7$; Ssh: Starry smooth hound, $n=7$; Sd: Spiny dogfish, $n=6$; Lsd: Lesser spotted dogfish, $n=8$.

(post-hoc Scheffe test, $p>0.05$ ). Black-mouthed catsharks and spiny dogfish were significantly depleted in ${ }^{13} \mathrm{C}$ in the muscle, compared to tope sharks and starry smooth hounds (post-hoc Scheffe test, $p<0.05$ ) but muscle $\delta^{13} \mathrm{C}$ values of these four species were similar to those of lesser-spotted dogfish (post-hoc Scheffe test, $p>0.05$ ). The same tendency was observed in the liver, but tope sharks did not differ from the other species whereas lesser-spotted dogfish were more depleted in ${ }^{13} \mathrm{C}$ than black-mouthed catsharks and spiny dogfish (post-hoc Scheffe test, $p<0.05$ ). 
Table 2

Influence of species (one-way ANOVA results, univariate specific effects) on metal concentrations and stable isotope ratios in the different tissues studied

\begin{tabular}{|c|c|}
\hline Factors & Species \\
\hline $\begin{array}{l}\text { Liver }(n=5) \\
\delta^{13} \mathrm{C} \\
\delta^{15} \mathrm{~N}\end{array}$ & $\begin{array}{l}F_{4,29}=7.19, p<0.0004 \\
F_{4,29}=19.24, p<0.000\end{array}$ \\
\hline $\begin{array}{l}\text { Kidney }(n=3) \\
\mathrm{Zn} \\
\mathrm{Cd} \\
\mathrm{Fe} \\
\mathrm{Cu} \\
\mathrm{Se}(\log )\end{array}$ & $\begin{array}{l}F_{2,14}=2.65, p>0.105 \\
F_{2,14}=3.67, p>0.052 \\
F_{2,14}=3.56, p>0.056 \\
F_{2,14}=0.18, p>0.83 \\
\boldsymbol{F}_{\mathbf{2 , 1 4}}=\mathbf{8 3 . 1 1}, \boldsymbol{p}<\mathbf{0 . 0 0 0}\end{array}$ \\
\hline $\begin{array}{l}\text { Muscle }(n=5) \\
\delta^{13} \mathrm{C} \\
\delta^{15} \mathrm{~N}(\log ) \\
\mathrm{Zn}(\log ) \\
\mathrm{Cd}(\log ) \\
\mathrm{Fe} \\
\mathrm{Cu}(\log ) \\
\mathrm{Se}(\log ) \\
\mathrm{Hg}(\log )\end{array}$ & $\begin{array}{l}F_{4.29}=7.58, p<0.0003 \\
F_{4.29}=34.51, p<0.000 \\
F_{4,29}=45.42, p<0.000 \\
F_{4,29}=12.23, p<0.000 \\
F_{4,28}=7.21, p<0.0004 \\
F_{4,21}=\mathbf{5 . 6 4}, p<0.003 \\
F_{4,28}=17.06, p<0.000 \\
F_{4,29}=\mathbf{2 0 . 0 3}, p<0.000\end{array}$ \\
\hline
\end{tabular}

Significant results are in bold characters, $p<0.005$; $(\log )$ indicates that the data were $\log$-transformed before statistical treatment to ensure a normal distribution; $n$ is the number of shark species taken into account.

\subsection{Metal levels in the tissues}

Mean trace metal levels are presented in Table 3 and ANOVA results in Table 2. $\mathrm{Ni}, \mathrm{Cr}$ and $\mathrm{Pb}$ values were under the detection limit and do not appear in Table 3.

Renal $\mathrm{Zn}, \mathrm{Cd}, \mathrm{Fe}$ and $\mathrm{Cu}$ concentrations in tope sharks, black-mouthed catsharks and starry smooth hounds remained similar across species while Se concentrations varied significantly between species (ANOVA, univariate results see Table 2). Starry smooth hounds displayed higher renal Se concentrations than tope sharks (post-hoc Scheffe test, $p<0.007$ ), which in turn were higher than those of black-mouthed catsharks (post-hoc Scheffe test, $p<0.05$ ). With the exception of tope sharks and black-mouthed catsharks which had Cd concentrations that were significantly similar between the kidney and the muscle, renal $\mathrm{Zn}$, $\mathrm{Cd}, \mathrm{Fe}, \mathrm{Cu}$ and $\mathrm{Se}$ concentrations were higher than those of muscle (ANOVA, $p<0.05)$.

The highest muscle $\mathrm{Zn}$ concentration (Table 3) was measured in lesser-spotted dogfish (post-hoc Scheffe test, $p<0.00001$ ) and those of tope sharks were higher than those of spiny dogfish (post-hoc Scheffe test, $p<0.023$ ). Starry smooth hounds and spiny dogfish displayed the lowest muscle Cd concentrations (post-hoc Scheffe test, $p<0.05)$. Lesser-spotted dogfish displayed higher muscle $\mathrm{Fe}$ and $\mathrm{Cu}$ concentrations than spiny dogfish (post-hoc Scheffe test, $p<0.0009$ and $p<0.016$, respectively) and 
Table 3

$\mathrm{Zn}, \mathrm{Cd}, \mathrm{Fe}, \mathrm{Cu}, \mathrm{Se}$ and $\mathrm{Hg}$ concentrations ( $\mu \mathrm{g} \mathrm{g}^{-1}$ dry weight) in the kidney and muscle of five commercial shark species from the Celtic Sea

\begin{tabular}{|c|c|c|c|c|c|c|c|}
\hline & & $\mathrm{Zn}$ & $\mathrm{Cd}$ & $\mathrm{Fe}$ & $\mathrm{Cu}$ & $\mathrm{Se}$ & $\mathrm{Hg}$ \\
\hline $\begin{array}{l}\text { Tope shark: } \\
\text { Galeorhinus galeus }\end{array}$ & Kidney & $\begin{array}{l}\mathbf{4 6}(\mathbf{5 5}) \pm \mathbf{2 0} \\
(6.5-58) \\
n=6 \\
\mathbf{1 6 . 5 ( 1 6 . 7 )} \pm \mathbf{2 . 4} \\
(13.1-19.3) \\
n=6\end{array}$ & $\begin{array}{l}<\mathbf{0 . 1 6} \\
n=6 \\
\mathbf{0 . 4}(\mathbf{0 . 4 )} \pm \mathbf{0 . 2} \\
(0.2-0.8) \\
n=6\end{array}$ & $\begin{array}{l}\mathbf{1 6 7}(\mathbf{1 7 4 )} \pm \mathbf{7 3} \\
(42-244) \\
n=6 \\
\mathbf{1 4 . 5}(\mathbf{1 4 . 7 )} \pm \mathbf{3 . 4} \\
(9-19.3) \\
n=6\end{array}$ & $\begin{array}{l}\mathbf{6 . 3}(\mathbf{6 . 7 )} \pm \mathbf{3 . 6} \\
(<0.3-10.2) \\
n=6 \\
\mathbf{1 . 1}(\mathbf{1}) \pm \mathbf{0 . 3} \\
(0.8-1.5) \\
n=6\end{array}$ & $\begin{array}{l}\mathbf{1 8 . 5}(\mathbf{1 8 . 2 )} \pm \mathbf{6 . 8} \\
(10.4-26) \\
n=6 \\
\mathbf{2 . 2}(2) \pm \mathbf{0 . 5} \\
(1.7-2.9) \\
n=6\end{array}$ & $\begin{array}{l}\mathbf{1 . 1}(\mathbf{1}) \pm \mathbf{0 . 6} \\
(0.5-1.9) \\
n=6\end{array}$ \\
\hline $\begin{array}{l}\text { Black-mouthed catshark: } \\
\text { Galeus melastomus }\end{array}$ & Kidney & $\begin{array}{l}\mathbf{6 2}(\mathbf{6 4 )} \pm \mathbf{5 . 9} \\
(55-69) \\
n=7 \\
\mathbf{1 4 . 5 ( 1 5 )} \pm \mathbf{1 . 6} \\
(12.3-16.6) \\
n=5\end{array}$ & $\begin{array}{l}\mathbf{1 . 4}(\mathbf{0 . 9}) \pm \mathbf{1 . 3} \\
(0.4-4.2) \\
n=7 \\
\mathbf{0 . 7}(\mathbf{0 . 6}) \pm \mathbf{0 . 6} \\
(<0.18-1.5) \\
n=7\end{array}$ & $\begin{array}{l}\text { bf } 289(226) \pm \mathbf{1 2 0} \\
(188505) \\
n=7 \\
\mathbf{1 5 . 6 ( 1 6 )} \pm \mathbf{2 . 3} \\
(11.9-18.8) \\
n=7\end{array}$ & $\begin{array}{l}\mathbf{5 . 6}(\mathbf{5 . 5 )} \pm \mathbf{1} \\
(4.6-7.6) \\
n=7 \\
\mathbf{1 . 2}(\mathbf{1 . 1}) \pm \mathbf{0 . 3} \\
(0.9-1.5) \\
n=7\end{array}$ & $\begin{array}{l}\mathbf{4 . 5}(\mathbf{4 . 5}) \pm \mathbf{0 . 6} \\
(3.8-5.3) \\
n=7 \\
\mathbf{1 . 1}(\mathbf{1}) \pm \mathbf{0 . 2} \\
(1-1.3) \\
n=7\end{array}$ & $\begin{array}{l}2.1(1.5) \pm 1.4 \\
(1-4.4) \\
n=7\end{array}$ \\
\hline $\begin{array}{l}\text { Starry smooth hound: } \\
\text { Mustelus asterias }\end{array}$ & Muscle & $\begin{array}{l}\mathbf{5 2}(\mathbf{5 1}) \pm 2.1 \\
(49-54) \\
n=4 \\
\mathbf{1 3 . 9}(\mathbf{1 3 . 3}) \pm \mathbf{1 . 8} \\
(12.1-16.8) \\
n=7\end{array}$ & $\begin{array}{l}\mathbf{0 . 8}(\mathbf{0 . 8}) \pm \mathbf{0 . 3} \\
(0.5-1.1) \\
n=4 \\
<\mathbf{0 . 1 7} \\
n=7\end{array}$ & $\begin{array}{l}\mathbf{3 0 2}(\mathbf{2 9 3}) \pm 57 \\
(242-380) \\
n=4 \\
\mathbf{1 2}(\mathbf{1 1 . 2 )} \pm \mathbf{4 . 1} \\
(8.2-20.1) \\
n=7\end{array}$ & $\begin{array}{l}\mathbf{6 . 3}(\mathbf{6 . 2}) \pm \mathbf{0 . 7} \\
(5.6-7.2) \\
n=4 \\
\mathbf{0 . 4}(\mathbf{0 . 4}) \pm \mathbf{0 . 4} \\
(<0.19-1.1) \\
n=7\end{array}$ & $\begin{array}{l}\mathbf{3 3}(\mathbf{3 3}) \pm \mathbf{5 . 7} \\
(2740) \\
n=4 \\
\mathbf{3}(\mathbf{2 . 6 )} \pm \mathbf{1} \\
(2.1-5.1) \\
n=7\end{array}$ & $\begin{array}{l}\mathbf{2 . 2}(\mathbf{2 . 1}) \pm \mathbf{0 . 5} \\
(1.7-3.1) \\
n=7\end{array}$ \\
\hline $\begin{array}{l}\text { Spiny dogfish: } \\
\text { Squalus acanthias }\end{array}$ & $\begin{array}{l}\text { Kidney } \\
\text { Muscle }\end{array}$ & $\begin{array}{l}\text { na } \\
\mathbf{1 0 . 1}(\mathbf{1 0 . 2}) \pm \mathbf{1 . 2} \\
(8.3-11.4) \\
n=6\end{array}$ & $\begin{array}{l}\text { na } \\
<0.16 \\
n=6\end{array}$ & $\begin{array}{l}\text { na } \\
8.8(8.6) \pm 1.4 \\
(7.2-11.1) \\
n=6\end{array}$ & $\begin{array}{l}\text { na } \\
<0.3 \\
n=6\end{array}$ & $\begin{array}{l}\text { na } \\
\mathbf{1 . 1}(\mathbf{1}) \pm \mathbf{0 . 2} \\
(0.8-1.3) \\
n=6\end{array}$ & $\begin{array}{l}\text { na } \\
\text { 0.2 (0.2) } \pm \mathbf{0 . 0 6} \\
(0.2-0.3) \\
n=6\end{array}$ \\
\hline $\begin{array}{l}\text { Lesser-spotted dogfish: } \\
\text { Scyliorhinus canicula }\end{array}$ & $\begin{array}{l}\text { Kidney } \\
\text { Muscle }\end{array}$ & $\begin{array}{l}\text { na } \\
49(42) \pm 26 \\
(32-111) \\
n=8\end{array}$ & $\begin{array}{l}\text { na } \\
\mathbf{1}(\mathbf{1}) \pm \mathbf{0 . 4} \\
(0.4-1.7) \\
n=8\end{array}$ & $\begin{array}{l}\text { na } \\
\mathbf{2 0 . 1}(\mathbf{1 8 . 4 )} \pm \mathbf{6 . 5} \\
(11.1-31.9) \\
n=7\end{array}$ & $\begin{array}{l}\text { na } \\
\mathbf{3 . 3}(\mathbf{1 . 5}) \pm \mathbf{5 . 2} \\
(0.9-15) \\
n=7\end{array}$ & $\begin{array}{l}\text { na } \\
\mathbf{1 . 7}(\mathbf{1 . 3 )} \pm \mathbf{0 . 8} \\
(1.1-2.9) \\
n=7\end{array}$ & $\begin{array}{l}\text { na } \\
\mathbf{1 . 9}(\mathbf{1 . 8}) \pm \mathbf{0 . 8} \\
(0.8-3.1) \\
n=8\end{array}$ \\
\hline
\end{tabular}

Data are expressed as mean (median) \pm standard deviation, range of concentrations (minimum-maximum); $n$ : number of samples; na: not available. 
starry smooth hounds (post-hoc Scheffe test, $p<0.02$ and $p<0.045$, respectively) whereas other species had intermediate values. Tope sharks and starry smooth hounds presented the highest muscle Se concentrations (post-hoc Scheffe test, $p<0.05)$ which were similar for other species. Starry smooth hounds display the highest muscle $\mathrm{Hg}$ concentrations, significantly higher than that of tope sharks, which in turn were higher than those of spiny dogfish (post-hoc Scheffe test, $p<0.05)$.

\subsection{Relationship between stable isotopes and trace metals}

A significant relationship was observed between hepatic $\delta^{15} \mathrm{~N}$ and renal $\mathrm{Cd}$ concentrations for all tope sharks, black-mouthed catsharks and starry smooth hounds considered (Parametric Spearman Correlation, $r=-0.55, p<0.02, n=17$, Fig. 3).

In tope sharks, a negative correlation existed between muscle $\delta^{13} \mathrm{C}$ and muscular Cd concentrations (Parametric Spearman Correlation, $r=-0.92, p=0.01, n=6$ ).

A significant relationship between muscle $\mathrm{Hg}$ concentrations and hepatic and muscle $\delta^{15} \mathrm{~N}$ values (Parametric Spearman Correlation, $r=0.42$ and 0.47 , respectively, $p<0.005, n=34$, Fig. 4) was observed for all species combined but when considered species-by-species, spiny dogfish gave a significant correlation between hepatic $\delta^{15} \mathrm{~N}$ and muscular $\mathrm{Hg}$ (Parametric Spearman Correlation, $r=0.86$, $p=0.028, n=6)$. Hg values were also correlated with the length of the five shark species and especially in tope sharks (Parametric Spearman Correlation, $r=0.39, n=34$ and $r=0.92, n=6$, respectively, $p<0.005)$.

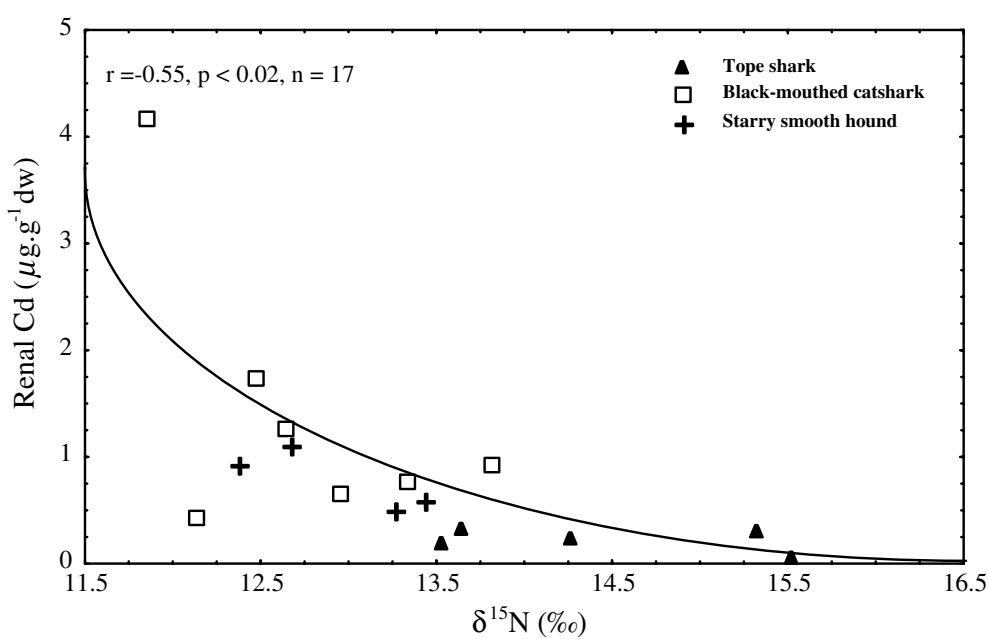

Fig. 3. Relationship between hepatic $\delta^{15} \mathrm{~N}$ values and renal $\mathrm{Cd}$ concentration in three shark species combined from the Celtic Sea. 


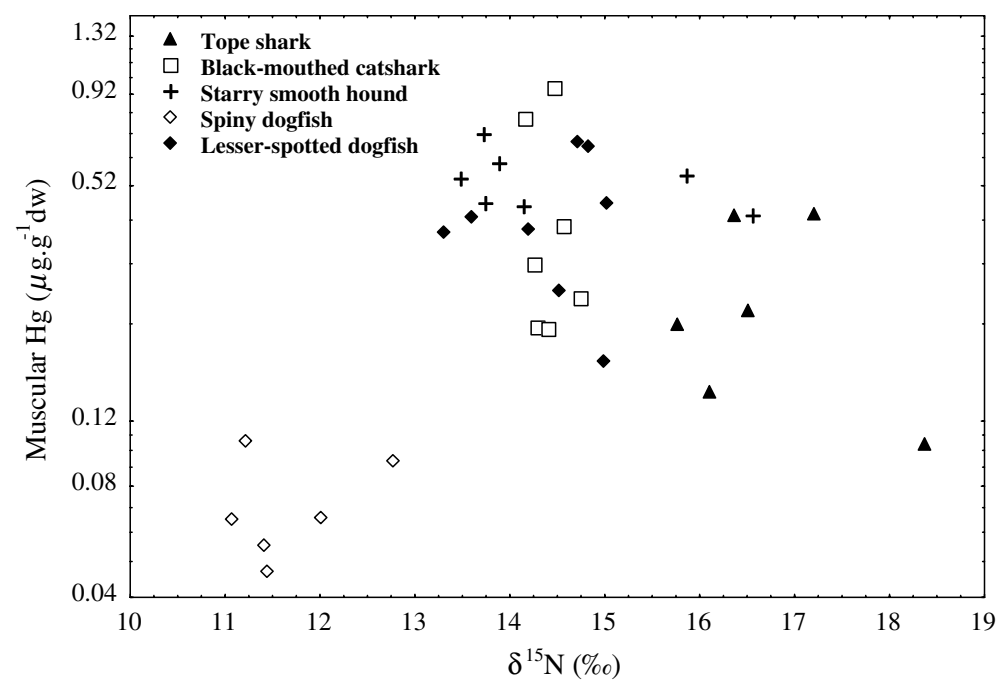

Fig. 4. Relationship between muscle $\delta^{15} \mathrm{~N}$ and $\mathrm{Hg}$ concentration using a log-scale in five shark species from the Celtic Sea.

\section{Discussion}

In the Celtic Sea, a wide range of $\delta^{15} \mathrm{~N}$ and $\delta^{13} \mathrm{C}$ values support the hypothesis of different feeding niches among the five shark species studied (as suggested by Ellis et al., 1996). The range of $\delta^{15} \mathrm{~N}$ values in the five species, between $11.6 \%$ for spiny dogfish and $16.7 \%$ for tope sharks, is similar to that observed in marine mammals from the Celtic Sea $(10.8 \%$ for striped dolphins, Stenella coeruleoalba, and a maximum of $15.8 \%$ in white-beaked dolphins, Lagenorhynchus albirostris, Das et al., 2003), thus showing their higher trophic level in the food web. The shark isotope signatures agree very closely (in terms of their relative distribution) with those listed in Pinnegar et al. (2002) which also suggested a higher $\delta^{15} \mathrm{~N}$ values for tope sharks and a much lower value for spiny dogfish. These authors have provided $\delta^{15} \mathrm{~N}$ values for fish species in the Celtic Sea and their isotopic data were slightly higher than those encountered in tope sharks, lesser-spotted dogfish, starry smooth hounds and spiny dogfish from this study. Within the Northeast Atlantic, stomach contents observed by Ellis et al. (1996) have revealed that the tope shark fed on invertebrates such as cephalopods (18.9\% of the diet) and mainly on epibenthic and pelagic fish species $(84.8 \%)$ such as clupeids, gadids or scombrids which reflected its mainly piscivorous diet. As the enrichment in ${ }^{15} \mathrm{~N}$ is about $3.4 \%$ per trophic level (Post, 2002) and as regards to the ${ }^{15} \mathrm{~N}$-isotopic signature of these potential preys (Pinnegar et al., 2002), carnivorous fishes such as poor cod Trisopterus minutus and grey gurnard Eutrigla gurnardus, zooplanktivorous fishes such as herring Clupea harengus, and also dragonet Callionymus lyra, plaice Pleuronectes platessa and mackerel Scomber scombrus, which prey mainly on invertebrates, might be present in higher quantities in the tope shark's diet. Starry smooth hounds, lesser spotted dogfish and 
black-mouthed catsharks have similar $\delta^{15} \mathrm{~N}$ values. These results are in agreement with previous diet studies based on stomach content analysis (Ellis et al., 1996) which show that their diet is mainly composed of invertebrates. Lesser-spotted dogfish are generalist feeders whose diet is composed mainly of crustaceans (46.37\%), annelids $(9.9 \%)$, molluscs $(4.17 \%$, mostly cephalopods) and also a large variety of small benthic and epibenthic fish species (22.51\%) (Ellis et al., 1996). Pinnegar et al. (2002) have recorded high $\delta^{15} \mathrm{~N}$ values for the usual fish prey items of lesser-spotted dogfish, showing that this species might feed on small fish individuals with a lower $\delta^{15} \mathrm{~N}$ signal such as blue whiting Micromesistius poutassou. Starry smooth hounds are specialist feeders who feed almost exclusively on crustaceans $(97.4 \%$ of the diet) (Ellis et al., 1996). Black-mouthed catsharks feed mainly on benthic invertebrates, including shrimp and more specifically cephalopods (Carasson, Stefanescu, \& Cartes, 1992; Velasco, Olaso, \& Sánchez, 2001), but also on small pelagic fish and other small elasmobranchs (Compagno, 1984; Cortès, 1999; Ellis et al., 1996).

Nevertheless, $\delta^{15} \mathrm{~N}$ values observed in spiny dogfish are in complete disagreement with previous stomach content studies. Spiny dogfish have the lowest $\delta^{15} \mathrm{~N}$ values, as well as those recorded by Pinnegar et al. (2002), granting them the lowest trophic level. Ellis et al. (1996) have recognised that spiny dogfish was a highly piscivorous species, with a diet mainly composed of pelagic and epipelagic fish (89.3\% of the diet) such as clupeids, gadids and scombrids (Ellis et al., 1996) which usually gives the species a high trophic level. There are a number of potential explanations for these low $\delta^{15} \mathrm{~N}$ values. Although most prey values seem too high to explain the low $\delta^{15} \mathrm{~N}$ observed for spiny dogfish (Pinnegar et al., 2002), some pelagic prey-fish species do however exhibit low $\delta^{15} \mathrm{~N}$ values, notably silvery pout Gadiculus argentius, boarfish Capros aper and blue whiting. The animals examined by Ellis et al. (1996) were collected in the Irish Sea, where such pelagic prey are much less abundant, thus diets may be very different in the Celtic Sea compared to the Irish Sea. In addition, elasmobranchs are slow-growing, and thus it is highly unlikely that their tissues change dramatically from season to season, and might indicate patterns of migration. Hesslein et al. (1993) demonstrated that for an adult teleost, white-muscle turnover took in excess of one full year. Several distinct spiny dogfish populations exist in the Northeast Atlantic that perform important migrations (Compagno, 1984; Holden, 1967; Quéro \& Vayne, 1997) and our individuals could come from a different area than the other species studied here, explaining the difference observed in the $\delta^{15} \mathrm{~N}$ values (Hansson et al., 1997). It is far more likely that the low $\delta^{15} \mathrm{~N}$ value indicates either depleted $\delta^{15} \mathrm{~N}$ prey sources or a biochemical peculiarity such as higher levels of urea or ammonia in the tissues. Fisk et al. (2002) hypothesized that the retention of important quantities of urea and trimethylamine oxide (TMAO) in the tissues of elasmobranchs for osmoregulation processes might cause an underestimation of the $\delta^{15}$ values. However, this hypothesis does not appear to be very plausible as it would only apply to the spiny dogfish and would not be in agreement with the data from the other species studied. Furthermore, the effects of the concentration of urea on $\delta^{15} \mathrm{~N}$ fractionation are poorly known and require more in-depth experiments to be determined. This hypothesis is also highly contested by Estrada et al. (2003), among others, who do not observe any underestimation of $\delta^{15} \mathrm{~N}$ values. 
Muscle $\delta^{15} \mathrm{~N}$ values are higher than those measured in liver in the five shark species. This difference in fish tissues can be related to differences in their biochemical composition, such as the predominant free amino-acids (e.g., carnosine, anserine and histidine) or prevalence of isotopically depleted urea displayed by some elasmobranch tissues (Van Waarde, 1988).

Dauby, Frankignoulle, Gobert, and Bouquegneau (1994) determined a $\delta^{13} \mathrm{C}$ value of $-23.9 \%$ for the suspended particulate matter in the present study area. This value, compared to those of the five shark species (Table 1), confirms their high position in the food web as there is a trophic enrichment in ${ }^{13} \mathrm{C}$ between successive trophic levels. Except for spiny dogfish, the $\delta^{13} \mathrm{C}$ pattern for liver data does not differ significantly from that of muscle. This could be a sign that the considered shark species did feed on the same carbon sources in the months previous to their capture. As previously observed with $\delta^{15} \mathrm{~N}$, the $\delta^{13} \mathrm{C}$ signature of spiny dogfish also supported that these species fed at a lower trophic level than tope sharks which displayed the highest values. However, the large variation in the $\delta^{13} \mathrm{C}$ signal in tope sharks could be the result of their obtaining their carbon from the same basal food source of spiny dogfish, a benthopelagic and oceanodromous species. Even if tope sharks are mainly demersal on continental shelves (Compagno, 1984), they could prey on pelagic as well as on benthic fish species, as already observed by Ellis et al. (1996) and by Morato-Gomes, Sola, Grós, Menezes, and Pinho (1998). $\delta^{13} \mathrm{C}$ is considered as a good indicator of the source of primary productivity and organic matter derived from pelagic sources in the marine environment is generally depleted in ${ }^{13} \mathrm{C}$ compared to the benthos (Hobson, 1999). Generally speaking, the $\delta^{13} \mathrm{C}$ values in the five shark species studied reflect a more varied diet. High trophic level organisms in marine ecosystems have been shown to have intermediate $\delta^{13} \mathrm{C}$ values due to the integration of different carbon sources (Hecky \& Hesslein, 1995). In summary, while stable isotopes of nitrogen and carbon have become useful tools to trace the feeding ecology of fishes, we have to be cautious when interpretating sharks' isotopic data. The lack of dietary taxonomic information in these animals and the need for constancy in baseline primary production isotope values across space and time suggest the interest of complementing these isotopic data by stomach content analysis.

A relationship between renal $\mathrm{Cd}$ concentrations and muscle isotopic $\delta^{15} \mathrm{~N}$ ratio were observed in tope sharks, black-mouthed catsharks and starry smooth hounds combined. The tendency observed is that as $\delta^{15} \mathrm{~N}$ increases, $\mathrm{Cd}$ concentration decreases with a minimum for the tope shark and this variation can be linked to dietary preference. Previous studies have shown the ability of cephalopods to concentrate $\mathrm{Cd}$ in the digestive gland, even in unpolluted areas like the Kerguelen Islands (Bustamante, Cherel, Caurant, \& Miramand, 1998a). Oceanic cephalopods from the Northeast Atlantic Ocean play an important role in the transfer of Cd in marine trophic food webs (Bustamante, Caurant, Fowler, \& Miramand, 1998b). The high renal $\mathrm{Cd}$ levels observed in black-mouthed catsharks are partly due to the ingestion of prey with low $\delta^{15} \mathrm{~N}$ and $\delta^{13} \mathrm{C}$ values and enriched in $\mathrm{Cd}$ such as oceanic cephalopods (Bustamante et al., 1998b; Carasson et al., 1992; Velasco et al., 2001). Considering the tope's piscivorous diet, lower Cd concentrations in its tissues were to be expected. In muscle tissues of tope sharks, the relationship between $\delta^{13} \mathrm{C}$ and $\mathrm{Cd}$ reflects a 
different exposure related to coastal vs. offshore feeding habitat, showing also that accumulation of $\mathrm{Cd}$ was probably diet related. No relationship was observed between $\mathrm{Zn}, \mathrm{Fe}$ or $\mathrm{Cu}$ values and isotopic composition in shark species suggesting that their high values were probably affected by other factors than diet such as growth rate or species-specific metabolism.

In tope sharks, black-mouthed catsharks and starry smooth hounds, $\mathrm{Zn}, \mathrm{Cd}, \mathrm{Fe}$, $\mathrm{Cu}$ and Se concentrations were more prominent in kidney than in muscle, except for $\mathrm{Cd}$ values which were similar in both tissues in tope sharks and black-mouthed catsharks. $\mathrm{Ni}, \mathrm{Cr}$ and $\mathrm{Pb}$ were not detected in the tissues of the five shark species. Lesser-spotted dogfish displayed the higher muscular $\mathrm{Zn}, \mathrm{Cd}, \mathrm{Fe}$ and $\mathrm{Cu}$ values compare to the other species, probably due to its benthic behaviour (Kress, Hornung, \& Herut, 1998; Leonzio, Bacci, Focardi, \& Renzoni, 1981). Trace metal concentrations of total $\mathrm{Hg}\left(2.3 \mu \mathrm{g} \mathrm{g}^{-1} \mathrm{dw}\right), \mathrm{Cd}\left(0.05 \mu \mathrm{g} \mathrm{g}^{-1} \mathrm{dw}\right), \mathrm{Zn}\left(37.6 \mu \mathrm{g} \mathrm{g}^{-1} \mathrm{dw}\right)$ and $\mathrm{Cu}(1.64$ $\left.\mu \mathrm{g} \mathrm{g}^{-1} \mathrm{dw}\right)$ measured previously in muscle of lesser-spotted dogfish by Cossa et al. (1990) in an adjacent area, the Bay of Biscay (ICES area VIIa), are of the same order of magnitude as those observed in the present study.

The highest levels of muscle $\mathrm{Hg}$ detected in starry smooth hounds, black-mouthed catsharks and lesser-spotted dogfish were mainly due to the fact that these animals are in close relation to the sediment and have a high trophic level (Kress et al., 1998; Storelli, Ceci, \& Marcotrigiano, 1998). Spiny dogfish displayed the lowest $\mathrm{Hg}$ concentrations which were probably linked to the low trophic level observed compared to the other four species studied and their limited exposure to contaminated sediments.In spite of their diet and high trophic level, tope sharks' $\mathrm{Hg}$ levels are lower than those of the other species (excepting spiny dogfish). These observations are probably due to the fact that tope sharks sampled for this study are juveniles (average $78 \mathrm{~cm}$ ), while the individuals from the other species were adults and have distinct feeding habits and have therefore been accumulating $\mathrm{Hg}$ in their tissues for a longer period of time. Also, young individuals have a higher growth rate than adults resulting in growth dilution and shorter exposure (Penedo de Pinho et al., 2002). The size at maturity of tope sharks is comprised between 120 and $130 \mathrm{~cm}$ (Compagno, 1984). Such variability in our results can be influenced by a number of factors, including biotic parameters such as size, ecology and trophic level (Adams \& McMichael, 1999; Greig, Wenzloff, Shelpuk, \& Adams, 1977; Penedo de Pinho et al., 2002; Storelli, Giacominelli-Stuffler, \& Marcotrigiano, 2002).

$\mathrm{Hg}$ exists in both organic and inorganic forms in the marine environment. Methylmercury, the most toxic organomercury compound, is formed in aquatic sediments by bacterial methylation of inorganic $\mathrm{Hg}$. It may comprise up to $90 \%$ of total $\mathrm{Hg}$ found in fish muscles (Storelli et al., 2001). Sharks generally absorb the pollutants through the diet and through their respiratory integuments (Walker, 1976). Due to increasing fish consumption (Wheeler, 1996) and Hg's high bioaccumulation and biomagnification capacity (Atwell, Hobson, \& Welch, 1998), fish are the most critical source of $\mathrm{Hg}$ for marine predators and also for human beings. Although the life history patterns of these shark species are diverse, sharks usually exhibit predatory behaviour, higher longevity, slower growth, lower metabolic rates, belong to higher trophic levels and therefore tend to have higher $\mathrm{Hg}$ concentrations than other fish 
(Lyle, 1984; Walker, 1976). A relationship has therefore been observed between $\mathrm{Hg}$ concentrations and $\delta^{15} \mathrm{~N}$ values in muscle tissue (Fig. 4) and also with length. Thus, the muscle $\mathrm{Hg}$ values, as encountered in starry smooth hounds, black-mouthed catsharks and lesser-spotted dogfish, are alarming if we refer to the total $\mathrm{Hg}$ contamination level limit for fish-products destined for food consumption which is regulated by the European Commission Decision (ECD) 93/351 of 19 May 1993 (Official Journal of the European Communities, 1994), asserting that the mean content of total $\mathrm{Hg}$ in edible parts of fish products should not exceed $0.5 \mathrm{mg} \mathrm{kg}^{-1}$ wet weight (i.e., 2.1 $\mathrm{mg} \mathrm{kg}^{-1} \mathrm{dw}$ in the sharks).

At similar trophic levels, marine mammals from the Northeast Atlantic display higher trace metal levels than the five shark species studied here. There is strong evidence that homeotherms accumulate much higher trace metal concentrations than poïkilotherms because of much higher feeding rates in the former (Fisk, Hobson, \& Norstrom, 2001).

The detoxification and trace metal elimination mechanisms in sharks are very poorly known, as well as the potential role of some tissues (i.e. the rectal gland and the gills) in different elasmobranch species. In the case of $\mathrm{Hg}$, biliary excretion is the primary pathway contributing to fecal methylmercury elimination (Boening, 2000). Storelli and Marcotrigiano (2002) have shown that the process of demethylation of methylmercury and inorganic $\mathrm{Hg}$ transformation in the liver by reaction with selenium to form mercuric selenide in the liver of tope sharks would be an effective mechanism for counteracting the potential damage of $\mathrm{Hg}$. The fact that we did not find any correlation between selenium and $\mathrm{Hg}$ concentrations in the muscle suggests that such a detoxification mechanism does not occur in these shark species' muscle tissues.

This study demonstrates the need to increase knowledge of elasmobranch physiology and ecology, to better understand the uptake and elimination paths of pollutants, and suggests dedicating more attention to the interpretation of stable isotope data as a single indicator of trophic level, as the lack of known trophic fractionation suggested that isotopic data be compared to traditional diet analyses. These results provide a baseline for future works on ecology of commercial shark species in the Northeast Atlantic.

\section{Acknowledgements}

We are grateful to Dr. Jim Ellis (CEFAS, Suffolk, United Kingdom) and to Dr Enric Cortès (National Marine Fisheries Service, Panama City Laboratory, Florida, USA) for their precious advice on the diet of our species. Thanks to Mrs. MarieHenriette Dubuit (Museum National d'Histoire Naturel, Concarneau, France), Dr. Pascal Lorance (IFREMER Brest, France) and M. Bernard Seret (IRD, Museum National d'Histoire Naturel, Paris, France) for their welcome and contributions in collecting the necessary samples for this study; Thanks to Mrs. Rachel Bouhy and Mr. Renzo Biondo (Oceanology Laboratory, Liege, Belgium) for their valuable technical assistance; Thanks to Dr. Gilles Lepoint and Mrs Fabienne 
Nyssen for their valuable advice and to Ms. Cristina Beans for reading this paper and ironing out the English. Thanks also to the three anonymous reviewers whose comments helped to improve this manuscript. Krishna Das received grants from the FNRS (Fonds National pour la Recherche Scientifique). This paper is MARE publication 064 .

\section{References}

Adams, D. H., \& McMichael, R. H. Jr., (1999). Mercury levels in four species of sharks from the Atlantic coast of Florida. Fisheries Bulletin, 97, 372-379.

Atwell, L., Hobson, K. A., \& Welch, H. E. (1998). Biomagnification and bioaccumulation of mercury in an artic food web: insights from stable nitrogen isotopes analysis. Canadian Journal of Fisheries and Aquatic Sciences, 55, 1114-1121.

Biessi, B. (1994). Les requins et les raies dans les pêcheries françaises. Mémoire Maîtrise de Biologie des Organismes et des Populations ( $30 \mathrm{p}$ ). Université Pierre et Marie Curie.

Boening, D. W. (2000). Ecological effects, transport, and fate of mercury: a general review. Chemosphere, 40, 1335-1351.

Bosley, K. L., Witting, D. A., Chambers, R. C., \& Wainright, S. C. (2002). Estimating turnover rates of carbon and nitrogen in recently metamorphosed winter flounder Pseudopleuronectes americanus with stable isotopes. Marine Ecology - Progress Series, 236, 233-240.

Bowen, W. D. (1997). Role of marine mammals in aquatic ecosystems. Marine Ecology-Progress Series, $158,267-274$.

Bustamante, P., Cherel, Y., Caurant, F., \& Miramand, P. (1998a). Cadmium, copper and zinc in octopuses from Kerguelen Islands, Southern Indian Ocean. Polar Biology, 19, 264-271.

Bustamante, P., Caurant, F., Fowler, S. W., \& Miramand, P. (1998b). Cephalopods as a vector for the transfer of cadmium to top marine predators in the north-east Atlantic ocean. Science of the Total Environment, 220, 71-80.

Carasson, M., Stefanescu, C., \& Cartes, J. E. (1992). Diets and bathymetric distributions of two bathyal sharks of the catalan deep-sea (Western Mediterranean). Marine Ecology - Progress Series, 82(1), 21-30.

Compagno, L. J. V. (1984). Sharks of the world: an annotated and illustrated guide of shark species known to date. FAO Species catalogue 4, Parts 1 and 2-FAO fisheries synopsis (Vol. 125, 655 p). Rome: FAO.

Cortès, E. (1997). A critical review of methods of studying fish feeding based on analysis of stomach contents: application to elasmobranchs fishes. Canadian Journal of Fisheries and Aquatic Sciences, 54, 726-738.

Cortès, E. (1999). Standardized diet compositions and trophic levels of sharks. ICES Journal of Marine Science, 56, 707-717.

Cossa, D., Auger, D., Averty, B., Luçon, M., Masselin, P., Noël, J., et al. (1990). Niveaux de concentration en métaux, métalloïdes et composés organochlorés dans les produits de la pêche côtière. Rapport IFREMER.

Das, K., Lepoint, G., Loizeau, V., Debacker, V., Dauby, P., \& Bouquegneau, J. M. (2000). Tuna and dolphin associations in the northeast Atlantic: evidence of different ecological niches from stable isotope and heavy metal measurements. Marine Pollution Bulletin, 40(2), 102-109.

Das, K., Beans, C., Holsbeek, L., Berrow, S. D., Rogan, E., \& Bouquegneau, J. M. (2003). Marine mammals from northeast Atlantic: evaluation of their trophic status by $\delta^{13} \mathrm{C}$ and $\delta^{15} \mathrm{~N}$ and influence on their trace metal concentrations. Marine Environmental Research, 56, 349-365.

Dauby, P., Frankignoulle, M., Gobert, S., \& Bouquegneau, J. M. (1994). Distribution of POC, PON, and particulate $\mathrm{Al}, \mathrm{Cd}, \mathrm{Cr}, \mathrm{Cu}, \mathrm{Pb}, \mathrm{Ti}, \mathrm{Zn}$ and $\delta^{13} \mathrm{C}$ in the English Channel and adjacent areas. Oceanologica Acta, 17(6), 643-657.

Dauby, P., Khomsi, A., \& Bouquegneau, J. M. (1998). Trophic relationships within intertidal communities of the Brittany coasts: a stable carbon isotope analysis. Journal of Coastal Research, 14(4), 1202-1212. 
Debacker, V., Schiettecatte, L. S., Jauniaux, T., \& Bouquegneau, J. M. (2001). Influence of age, sex, and body condition on zinc, copper, cadmium and metallothioneins in common guillemots (Uria aalgae) stranded at the Belgian coast. Marine Environmental Research, 52, 427-444.

De Niro, M. J., \& Epstein, S. (1978). Influence of diet on the distribution of carbon isotopes in animals. Geochimica et Cosmochimica Acta, 42, 495-506.

De Niro, M. J., \& Epstein, S. (1981). Influence of diet on the distribution of nitrogen isotopes in animals. Geochimica et Cosmochimica Acta, 45, 341-351.

Ellis, J. R., Pawson, M. G., \& Shackley, S. F. (1996). The comparative feeding ecology of six species of sharks and four species of ray (Elasmobranchii) in the north-east Atlantic. Journal of the Marine Biological Association of the United Kingdom, 76, 89-106.

Estrada, J. A., Rice, A. N., Lutcavage, M. E, \& Skomal, G. B. (2003). Predicting trophic position in sharks of the North-west Atlantic ocean using stable isotope analysis. Journal of the Marine Biological Association of the United Kingdom, 83, 1347-1350.

Fisk, A. T., Hobson, K. A., \& Norstrom, R. J. (2001). Influence of chemical and biological factors on trophic transfer of persistent organic pollutants in the Northwater Polynya marine food web. Environmental Science and Technology, 35, 732-738.

Fisk, A. T., Tittlemier, S. A., Pranschke, J. L., \& Norstrom, R. J. (2002). Using anthropogenic contaminants and stable isotopes assess the feeding ecology of Greenland sharks. Ecology, 83(8), 2162-2172.

Forrester, C. R., \& Ketchen, K. S. (1972). Mercury content of spiny dogfish (Squalus acanthias) in the Strait of Georgia, British Columbia. Journal of Fisheries Research Board of Canada, 29, 14871490.

Fry, B., \& Sherr, E. B. (1988). $\delta^{13}$ C measurements as indicators of carbon flow in marine and freshwater ecosystems. In Stable isotopes: Integration of biological ecological and geochemical processes. In H. Griffiths (Ed.). Environmental plant biology series (pp. 196-229). Bios Scientific Publishers.

Greig, R. A., Wenzloff, D., Shelpuk, C., \& Adams, A. (1977). Mercury concentration in three species of fish from North Atlantic offshore waters. Archives of Environmental Contamination and Toxicology, $5(3), 315-323$.

Hansson, S., Hobbie, J. E., Elmgren, R., Larsson, U., Fry, B., \& Johansson, S. (1997). The stable nitrogen isotope ratio as a marker of food-web interactions and fish migration. Ecology, 78(7), 2249-2257.

Hecky, R. E., \& Hesslein, R. H. (1995). Contributions of benthic algae to lake food webs as revealed by stable isotopes analysis. Journal of the North American Benthic Society, 14, 631-653.

Hesslein, R. H., Hallard, K. A., \& Ramlal, P. (1993). Replacement of sulfur, carbon, and nitrogen in tissue of growing broad whitefish (Coregonus nasus) in response to a change in diet traced by $\delta^{34} \mathrm{~S}, \delta^{13} \mathrm{C}$ and $\delta^{15}$ N. Canadian Journal of Fisheries and Aquatic Sciences, 50(10), 2071-2076.

Hobson, K. A. (1993). Trophic relationships among high Arctic seabirds: insights from tissue-dependent stable-isotope models. Marine Ecology - Progress Series, 95, 7-18.

Hobson, K. A. (1999). Tracing origins and migration of wildlife using stable isotopes: a review. Oecologia, 120, 314-326.

Hobson, K. A., \& Welch, H. E. (1992). Determination of trophic relationships within a high Arctic food web using $\delta^{13} \mathrm{C}$ and $\delta^{15} \mathrm{~N}$ analysis. Marine Ecology - Progress Series, 84, 9-18.

Hobson, K. A, Piatt, J. F., \& Pitocchelli, J. (1994). Using stable isotopes to determine seabird trophic relationships. Journal of Animal Ecology, 63, 786-798.

Hobson, K. A., Ambrose, W. G., \& Renaud, P. E. (1995). Sources of primary production, benthic-pelagic coupling, and trophic relationships within the Northeast water polynia: insights from $\delta^{13} \mathrm{C}$ and $\delta^{15} \mathrm{~N}$ analysis. Marine Ecology - Progress Series, 128, 1-10.

Holden, M. J. (1967). Transatlantic movement of a tagged spurdogfish. Nature, 21(10), 1140-1141.

Jarman, W. M., Hobson, K. A., Sydeman, W. J., Bacon, C. E., \& McLaren, E. B. (1996). Influence of trophic position and feeding location on contaminant levels in the gulf of the Farallones food web revealed by stable isotope analysis. Environmental Science and Technology, 30(2), 654-660.

Joiris, C. R., Holsbeek, L., Bouquegneau, J. M., \& Bossicart, M. (1991). Mercury contamination of the harbour porpoise Phocoena phocoena and other cetaceans from the North Sea and the Kattegat. Water Air and Soil Pollution, 56, 283-293. 
Kai, N., Hueda, T., Takeda, Y., \& Kat, A. (1987). Accumulation of mercury and selenium in blue marlin. Nippon Suisan Gakkaishi, 53(9), 1697.

Kress, N., Hornung, H., \& Herut, B. (1998). Concentrations of $\mathrm{Hg}, \mathrm{Cd}, \mathrm{Cu}, \mathrm{Zn}, \mathrm{Fe}$ and $\mathrm{Mn}$ in deep sea benthic fauna from the southeastern Mediterranean Sea: a comparison study between fauna collected at a pristine area and at two waste disposal sites. Marine Pollution Bulletin, 36, 911-921.

Leah, R., Evans, S., \& Johnson, M. (1991). Mercury in muscle tissue of lesser-spotted dogfish (Scyliorhinus caniculus L.) from the north-east Irish Sea. Science of the Total Environment, 108(3), 215-224.

Leonzio, C., Bacci, E., Focardi, S., \& Renzoni, A. (1981). Heavy metals in organisms from the Northern Tyrrhenian Sea. Science of the Total Environment, 20, 131-146.

Lyle, J. M. (1984). Mercury concentrations in four Carcharhinid and three hammerhead sharks from coastal waters of the northern territory. Australian Journal of Marine and Freshwater Research, 35, $441-451$.

Mejuto Marti, C. M., Bollain Rodriguez, M. H., \& Martinez, F. B. (1987). Fluorimetric determination of selenium in human tissues. Analysis, 15, 420-423.

Michener, R. H., \& Schell, D. M. (1994). Stable isotopes ratios as tracers in marine aquatic foodwebs. In K. Lattjha \& R. H. Michener (Eds.), Stable isotopes in ecology and environmental science (pp. 138-186). Oxford, UK: Blackwell Scientific Publications.

Meaburn, G. M. (1978). Heavy metal contamination of Spanish mackerel, Scomberomorus maculates, and king mackerel, S. cavalla. Proceedings of the mackerel colloquium, 16(March), 61-66.

Miller, G. E., Grant, P. M., Kishore, R., Steinkruger, F. J., Rowland, F. S., \& Guinn, V. P. (1972). Mercury concentrations in museum specimens of tuna and swordfish. Science (Washington, DC), 175, $1121-1122$.

Official Journal of the European Communities. (1994). L144 of 16 June.

Morato-Gomes, T., Sola, E., Grós, M. P., Menezes, G., \& Pinho, M. R. (1998). Trophic relationships and feeding habits of demersal fishes from the Azores: importance to multispecies assessment. ICES CM 1998/O:7. $21 \mathrm{pp}$.

Olive, P. J. W., Pinnegar, J. K., Polunin, N. V. C., Richards, G., \& Welch, R. (2003). Isotope trophic-step fractionation: a dynamic equilibrium model. Journal of Animal Ecology, 72, 608-617.

Owens, N. J. P. (1988). Natural variations in ${ }^{15} \mathrm{~N}$ in the marine environment. Advances in Marine Biology, 24, 389-451.

Pauly, D., Trites, A., Capuli, E., \& Christensen, V. (1998). Diet composition and trophic levels of marine mammals. ICES Journal of Marine Science, 55, 467-481.

Penedo de Pinho, A. P., Guimarães, J. R. D., Martins, A. S., Costa, P. A. S., Olavo, G., \& Valentin, J. (2002). Total mercury in muscle tissue of five shark species from Brazilian offshore waters: effects of feeding habit, sex, and length. Environmental Research, 89, 250-258.

Peterson, B. J., \& Fry, B. (1987). Stable isotopes in ecosystem studies. Annual Review of Ecology and Systematics, 18, 293-320.

Pinnegar, J. K., \& Polunin, N. V. C. (1999). Differential fractionation of $\delta^{13} \mathrm{C}$ and $\delta^{15} \mathrm{~N}$ among fish tissues: implications for the study of trophic interactions. Functional Ecology, 13, 1-7.

Pinnegar, J. K., Jennings, S., O’Brien, M., \& Polunin, V. C. (2002). Long-term changes in the trophic level of the Celtic Sea fish community and fish marked price distribution. Journal of Applied Ecology, 39, $377-390$.

Post, D. M. (2002). Using stable isotopes to estimate trophic position: models, methods and assumptions. Ecology, 83, 703-718.

Quéro, J. C., \& Vayne, J. J. (1997). Les poissons de mer des pêches françaises. Delachaux et Niestlé SA, Lausanne-Paris, $304 \mathrm{p}$.

Storelli, M. M., Ceci, E., \& Marcotrigiano, G. O. (1998). Comparative study of heavy metal residues in some tissues of the fish Galeus melastomus caught along the Italian and Albanian coasts. Rapport de la commission International pour la Mer Méditerranée, 35, 288-289.

Storelli, M. M., Giacominelli-Stuffler, R., \& Marcotrigiano, G. O. (2001). Total mercury and methylmercury in tuna fish and sharks from the south Adriatic Sea. Italian Journal of Food Science, 1(13), 101-106. 
Storelli, M. M., Giacominelli-Stuffler, R., \& Marcotrigiano, G. O. (2002). Total and methylmercury residues in cartilaginous fish from Mediterranean Sea. Marine Environmental Bulletin, 68, 201-210.

Storelli, M. M., \& Marcotrigiano, G. O. (2002). Mercury speciation and relationship between mercury and selenium in liver of Galeus melastomus from the Mediterranean Sea. Bulletin of Environmental Contamination and Toxicology, 69, 516-522.

Van Waarde, A. (1988). Biochemistry of non-protein nitrogenous coumponds in fish, including the use of amino acids for anaerobic energy production. Comparative Biochemistry and Physiology, 91, 207-228.

Vander Zanden, M. J., Cabana, G., \& Rasmussen, J. B. (1997). Comparing trophic position of freshwater fish calculated using stable isotope ratios $\left(\delta^{15} \mathrm{~N}\right)$ and literature dietary data. Canadian Journal of Fisheries and Aquatic Science, 54, 1142-1158.

Velasco, F., Olaso, I., \& Sánchez, F. (2001). The role of cephalopods as forage for the demersal fish community in the southern bay of Biscay. Fisheries Research, 52, 65-77.

Walker, T. I. (1976). Effects of species, sex, length and locality on the mercury content of school shark Galeorhinus australis (Macleay) and gummy shark Mustelus antarcticus Güenther from South-eastern Australian waters. Australian Journal of Marine and Freshwater Research, 27, 603-616.

Wheeler, M. (1996). Measuring mercury. Environmental Health Perspectives, 104, 826-830. 